
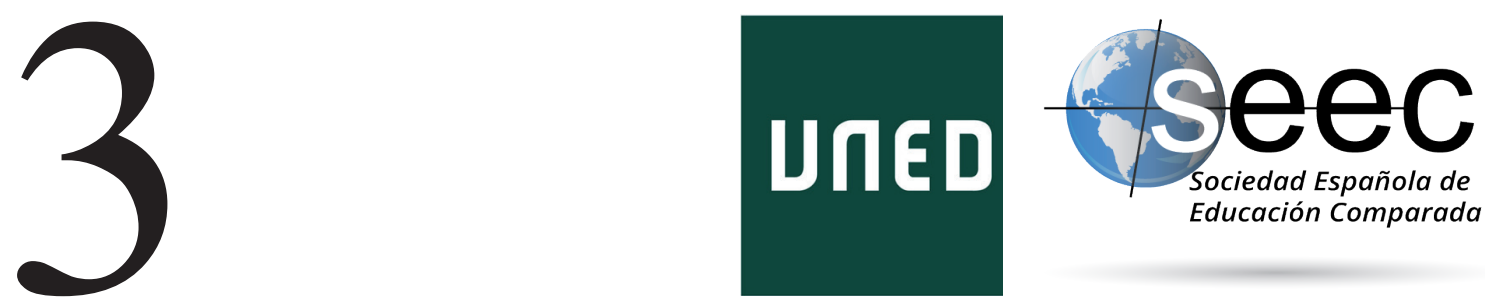

\title{
Adding new "C"s to our lexicon when considering the future of comparative education research: Complexity, care, and caution
}

\author{
Agregando nuevas "C" a nuestro léxico \\ sobre el futuro de la investigación en educación \\ comparada: complejidad, cuidado y cautela
}

\section{Steve Sider*}

DoI: $10.5944 /$ reec.40.2022.31312

Recibido: 6 de agosto de 2021 Aceptado: 1 de noviembre de 2021

\footnotetext{
*STEVE SidER: Dr. Steve Sider is a professor in the Faculty of Education at Wilfrid Laurier University in Waterloo, Canada where he teaches courses in global education, school leadership, and inclusive education. He currently holds three Canadian national research grants examining inclusive leadership practices of Canadian school principals. He travels regularly to Haiti, Ghana, and Egypt where he is involved in school leadership and special education training and research. He is the 2019 winner of the Laurier Donald F. Morgenson Faculty Award for Teaching Excellence in the category of Excellence in Internationalization. He is the inaugural program coordinator for the Laurier Bachelor of Arts in International Education Studies program, the first of its kind in Canada. Prior to his work in the Faculty of Education, Dr. Sider was a school administrator, special education teacher, and classroom teacher for 15 years. He is on the executive of the Comparative and International Education Society of Canada (CIESC). Datos de contacto: E-mail: ssider@wlu.ca. ORCID: https://orcid. org/o0oo-0002-4331-7388
} 


\begin{abstract}
This article explores the question "What can inclusive comparative and international education research look like?" I situate my own experience in comparative research to consider three "Cs" for the future of comparative and international education: Complexity, care, and caution. Complexity refers to the divisive and challenging global issues that exist and in which comparative education research takes place. As comparative and international education researchers, we need to practice an ethic of care in engaging in research in increasingly complex times. I conclude by providing three cautions for the future of research: transparency, positionality, and ethical relationality.
\end{abstract}

Keywords: Comparative education; complexity; care; inclusive education; Canada.

\title{
Resumen
}

Este artículo trata de responder a la pregunta "¿Cómo puede ser inclusiva la investigación en educación comparada e internacional?" Sitúo mi propia experiencia en la investigación comparada, para considerar tres "C" en el futuro de la educación comparada e internacional: complejidad, cuidado y cautela. La complejidad se refiere a los problemas globales divisivos y desafiantes que existen y en los que se lleva a cabo la investigación en educación comparada. Como investigadores en educación comparada e internacional, debemos practicar una ética del cuidado al participar en la investigación en tiempos cada vez más complejos. Concluyo proporcionando tres advertencias para el futuro de la investigación: transparencia, posicionalidad y relacionalidad ética.

Palabras clave: educación comparada; complejidad; cuidado; educación inclusiva; Canadá. 


\title{
1. Introduction
}

The focus of this volume on creativity, curiosity, and new thinking in comparative education, along with preparing the President's Address for the annual meeting of the Comparative and International Education Society of Canada (CIESC), provided me with a wonderful opportunity to imagine the future of comparative and international education. I am particularly pleased to note that a framing quote for this volume was provided by Marianne Larsen, a colleague and former president of CIESC. She challenged those in comparative and international education to consider, "a new and fresh thought in relation to what we study; the interpretative concepts, frames and theories that we develop in our work, the influences and contexts which mold the work we undertake as comparativists" (Larsen, 2013). In this paper, I follow a narrative, experience-oriented approach to fuse my research and my experience in comparative and international education to consider Larsen's challenge and to specifically explore the question: What can inclusive comparative and international education research look like? I focus specifically on the research aspect of what we do as comparativists and draw on the work of national and global scholars to help provide some new thinking in this area.

I begin by drawing on the work of Dwayne Donald, an Indigenous scholar from Canada, who encourages us to frame our work in and through relationships. He states that,

\begin{abstract}
"What is required for knowledge to become organic and make a claim on us that will facilitate a necessary shift in our understanding is a storied approach to knowledge that helps us see ourselves implicated in and in relation to what it is that we want to know... For teaching and learning to be meaningful, we need to see ourselves in ecological relation to that which we want to know. Relations always come first. This is what stories teach us." (Donald, 2013, p. 19)
\end{abstract}

Thus, in this paper I first situate myself in relationship to my story, my lived experience. I follow a narrative inquiry approach that is centered in my own experience. This approach is based on the work of Jean Clandinin and others who have framed this type of reflective research (Clandinin, 2013; Clandinin \& Connelly, 2004; Clandinin \& Connelly, 1998). This form of research is aligned with Indigenous epistemologies which I draw on as well (Cardinal et al., 2019). I do not provide further explanation of these approaches to research but encourage readers to explore the work of Jean Clandinin in regard to narrative inquiry and the work of Indigenous scholars such as Dwayne Donald, Marie Battiste, and Jacqueline Ottman who write about decolonizing education. I then explore three aspects that can frame some of our thinking about what inclusive comparative and international education research can look like going forward. I used three words, each beginning with the letter "C", to frame the second part of the article: Complexity, care, and caution.

\section{Positioning myself: How I came to comparative and international education}

I grew up and had my early schooling in India. I completed my schooling in Canada, eventually becoming a teacher. I remained intrigued with comparative and international 
education as a secondary school teacher. During this time, I taught courses on world history and global economics. For a portion of this time, I taught in an international school with students from around the world. I led experiential learning opportunities for my students, traveling with them to countries such as Thailand, Venezuela, and France. I thoroughly enjoyed the process of helping my students develop a broader perspective on the world.

I pursued graduate studies while I was a teacher and school administrator, partly just because I loved to learn. Eventually, I found a PhD program (actually, a PhD program found me, but that is another story). My supervisor was Dr. Suzanne Majhanovich who had been the president of the CIESC and had been an active member in the World Council of Comparative Education Societies (WCCES) and the Comparative and International Education Society (CIES). Although I had been a teacher who was committed to global education and perspective-building, I did not yet know about the formal scholarship of comparative and international education. I was incredibly fortunate to have one of the leading Canadian scholars in the field as my supervisor. Under Dr. Majhanovich's mentoring, I became increasingly involved with CIESC, initially serving on the board as a member at large and then as the treasurer-secretary, vice-president, president, and now as the past-president. During this time, my scholarship in comparative and international education ranged from case studies situated in Haiti (Sider, 2014) to descriptive program evaluation research in Egypt (Sider, 2019). Recent scholarship has explored global agreements, such as the Sustainable Development Goals, in fragile contexts such as Haiti (Sider et al., 2021a).

As I have engaged in comparative and international education research, I have increasingly recognized the substantial privileges that I have experienced. My lived experience has been framed by my cultural and racial background as a white person, the child of development workers, growing up in an area of India that is considered one of the poorest in the country. As a child, I spoke Hindi as my first language. I soon recognized the power of the English language as a result of an international boarding school experience. The school, nestled in the Himalayan foothills, connected me with children from around the world but separated me from the community that I considered home. Later, I was privileged through the support I received from school teachers who helped me transition to Canada; I recognize that not every child has these benefits. As a teacher, I was able to travel with students who were also privileged to have families who had the economic ability to support travel. The list of my privileges is substantial. I have lived in the tension of the guilt that goes along with these privileges and the acknowledgement that access to these privileges does not absolve me from trying to understand what it means to live in community, in Dwayne Donald's words noted above, in relationship. One thing that I have learned about comparative and international education is that there are lots of tensions and complexities and my own lived experience is representative of this.

My research for the past ten years has focused on how educators can support the inclusion of students with disabilities in Canada and other contexts including Haiti and Ghana. My publications tend to focus on the intersection of inclusion, school leadership, and comparative education (e.g., Sider, 2020, Sider et al., 2019; Sider et al., 2021a). A key premise of my research is that school leaders, no matter the context, are critical actors in the degree to which schools and school systems include students with disabilities. If school leaders model and teach inclusive practices, teachers and community members tend to be much more supportive of ensuring that all children, no matter the ability or 
disability, are included in the local school. It is important to note this research before proceeding because it is part of my story and I draw on it to examine how comparative and international education can aim to be inclusive going forward.

\subsection{Looking forward: New Cs for Comparative Education}

Over the past 20 years, scholarly and popular writers have challenged educators to foster so-called 21st century skills in students (see, for example, Fullan et al., 2017). These skills are sometimes referred to as global competencies (OECD, 2018) and often are referenced in the English language to "the Cs" since they begin with the letter "C", for example, collaboration, critical thinking, and creativity. The idea of 21st century skills or global competencies can be a problematic, neo-liberal concept as the identified skills and knowledge may be closely associated with corporate interests in the global North (Bacchi \& Goodwin, 2016; Olssen \& Peters, 2005, Rizvi \& Lingard, 2010). The espoused global competencies may not represent or even benefit those who live in complex, fragile contexts. So, in this article, I provide a counter-narrative, "new Cs", that is, words that begin with " $\mathrm{C}$ " that I would propose can help us consider new ways forward in comparative and international education research. These words are: complexity, care, and caution.

\subsection{Complexity}

We often talk about commonalities in the human experience but the global COVID-19 pandemic has demonstrated the contrasts in our lived experiences and massive socioeconomic-political divides. For example, anti-Black, anti-Muslim, and anti-Asian racism has been highlighted through violent acts in the United States, Canada, the United Kingdom, and beyond. In Canada, we have also seen anti-Indigenous racism and disturbing discoveries such as the unmarked graves of 10os of Indigenous children who were part of residential schools for Indigenous children. In one particularly recent gruesome discovery, 215 bodies were found in an unmarked mass grave at a former residential school in Kamloops, British Columbia. Other unmarked graves have been found and Indigenous Knowledge-Keepers suggest that many more will still be identified (NPR, 2021). In other contexts of the world, there have been glaring disparities demonstrated in the experiences of farmers in India, the introduction of cholera to Haiti via United Nations troops, and the tragic experiences of refugees in many parts of the world in their effort to escape conflict. In many contexts, we are learning about "intercultural competencies" while others are experiencing seemingly ever-increasing conflict. The irony of this should not be lost on us.

The COVID-19 pandemic seems to have exacerbated the divides that exist as even vaccine distributions have seen a clear demarcation between access to vaccines in the global North and the global South. Further, the COVID-19 pandemic has demonstrated that we are living closer than ever before in global community due to technology while, at the same time, being greatly divided. Information about COVID-19 is rapidly broadcast via traditional and social media. In the early days of vaccine distribution, we became aware of the lack of vaccines in countries like India despite the fact that it is the world's largest producer of vaccines (Frayer, 2021). Further illustrative of the divides that are growing is a deeply personal one: I can have a research team meeting with university colleagues in Haiti via Zoom but am not living the reality of many of those same colleagues who are not being paid for months on end. Perhaps the divides that exist in the world could be best illustrated through the responses to two questions: Who has access 
to vaccines? Who has access to technology? The issues of vaccines and technology are but two ways in which global divides can be illustrated.

These issues raise questions related to the relevance of comparative and international education in this complex era. It also challenges us to consider what comparative and international education "means" in this new age of remote learning and connectivity, of uneven and inequitable access to basic health care. What does "international" mean in an era of trans-nationalism (Vertovec, 2009)? An illustration of this that I experienced recently was through the Third Annual WCCES Symposium that was held in November 2020. There were many presentations involving scholars from the global South which was wonderful. If you had access to technology, you had access to the conference. However, it was clear that some scholars from the global South were not able to participate because they did not have access to the technology that would allow them to participate. The symposium illustrated that scholars could engage in research and presentations beyond national borders. Yet, it also illustrated that many still did not have access to an international audience. For them, transnationalism is a concept not reflected through their experience. How will we as comparativists include all scholars, not just those with access to technology or funding in the future?

My own research with colleagues in Haiti and Ethiopia has illustrated this divide. Even if access to technology is available, research meetings have demonstrated the incredible divides that exist. For example, in a recent research team meeting, colleagues in Nepal, India, Ghana, and Haiti talked about friends and family members who had not been able to access basic health care during the COVID-19 pandemic. Thus, technology brought us together but demonstrated how divided we were, exemplifying that "although the world may be increasingly interconnected, global systems of inequality, power, privilege, and difference are always present" (Zemach-Bersin, 2008, A34). If power and privilege are always present, how can scholars of comparative and international education be inclusive of all?

The complexity of this temporal period reminds us that there are certainly multidimensional, intersecting aspects of comparative education research. It is difficult to identify and examine isolated issues. Simple solutions are not possible. Instead, we need to recognize that complexity is what enriches comparative and international education. Paul Tarc, a colleague from Canada has written extensively on international education, and has stated that international education is full of "ambiguities, contradictions, and tensions" (Tarc, 2013, p. 5). As we look to the future of comparative and international education research, we need to acknowledge that complexity is at the core of what we do. It is what makes the study of comparative and international education both incredibly challenging and incredibly rewarding. It is in the complexity of individual lived experiences and massive systemic challenges that research in comparative and international education can and must "pull back the curtain" of human experience. We know that "... experiences alone do not make a person a multicultural or global educator. It is the interrelationships across identity, power, and experience that lead to a consciousness of other perspectives and a recognition of multiple realities" (Merryfield, 2000, p. 440). I will return to this ideas of relationships as a foundation of inclusive research in comparative and international education.

Complexity can cause us to be exasperated and exhausted; it can be overwhelming. One of the challenges that comparative and international education faces is how to "work" IN this terrain while also addressing how to work THE terrain. In other words, 
how do we examine and critique the structural and systemic issues that pervade our institutions, our local communities, and our global ones too while also striving for some level of hope? How do we not over-simplify complex local and global challenges? How do we ensure that we do not conclude the chapter or manuscript too quickly without acknowledging the complexities of contexts and of the research we engage in? I have been thinking recently that perhaps we need to replace the term "conclusions" in articles and chapters with "continuances" and "ongoing complexities"? One of my "continuances" in this complex time is a recognition that I need to consistently examine not only the structural but the deeply personal aspects of comparative and international education. While recognizing that the structural must be critiqued, I must also answer the questions: What am I doing to address the divides that exist in these complex times? How am I being inclusive in my own research? To respond to these questions, I turn to another "C", care, that I posit as fundamentally important as we consider the complexity of comparative and international education going forward.

\subsection{Care}

Mel Ainscow stated that, "The issue of how to build more inclusive forms of education is arguably the biggest challenge facing school systems throughout the world" (Ainscow \& Sandill, 2010, p. 401). Inclusive education is at the centre of my research and I believe it provides an important consideration for the future of comparative and international education. Inclusive education is premised on the belief that every child, no matter their strengths or needs, belongs in their neighbourhood school (Sider et al., 2021b). It is holistic and considers the child as a full member of the community, be that the school community or the local neighbourhood. Including students with disabilities and special education needs in their local school should reflect what we hope for from society. Inclusive education is communal; every person in a community is a full participating member of that community and responsible to ensure that others are welcomed as full participating members. It recognizes strengths in every child and sees needs that children have as gifts or assets. In many ways, inclusive education is a reflection of Indigenous perspectives on community where everyone is welcomed and honoured (Absolon, 2016). Relational space is the heartbeat of inclusive education. It emphasizes the importance of every voice being heard, of every child feeling included. It is premised on an ethic of care.

I have been exploring the intersection of disability and school leadership in Canada and beyond. My work particularly focuses on students with significant and complex needs and how school leaders - whether in Canada, Haiti, Ghana, Egypt, or St. Lucia can foster inclusive skills and attitudes and support teachers to authentically include all students in their classrooms. Comparative and international education provides a space for this type of research and these types of conversations. Comparative and international education research frameworks on inclusive education provide opportunities to better understand inclusive education from a contextualized, localized, and relational perspective (Schuelka \& Lapham, 2019). As a result, I have taken an explicitly comparative perspective in my research on inclusive education in Canada, Haiti, and Ghana.

Our research has demonstrated that local contexts can inform broader knowledge and vice versa. For example, the inclusive education policy framework in Ghana is fairly robust, although there is a significant gap between policy and practice. By contrast, Haiti does not have a policy framework on inclusive education, thus there is potential for our research in Ghana to inform policy development in Haiti. When sharing some of our 
research in international and comparative contexts with an administrator in Haiti, she told us that, "If I want to see large-scale change occur, I have to work not only with the Ministry of National Education but, even more importantly, I have to build bridges with people in this region and beyond." Recognizing the value of comparative and international research in informing localized practices is an important way in which our research can have impact. At the same time, we have to be aware and cautious of transplanting research and policies from one jurisdiction to another. Localized knowledges and practices must always be at the centre of our international research. Working with local scholars and communities of practice fosters relationships and leads to better research outcomes. Reciprocity should be at the heart of our local-global research engagement.

In Ghana, we are exploring a major gap between inclusive education practices in private and public schools. Haiti has a high portion of children attending low-fee private schools, thus, once again, the research in Ghana is critical to inform inclusive education policy and accountability frameworks in both private and public schools beyond Ghana. Another way in which this research is informing practice is regarding how to effectively support students with complex developmental needs. In Haiti, we have documented examples of how teachers have been able to support complex needs in large classes with few resources. Research has demonstrated that including all students in the regular class rather than in separate congregated classes benefits all learners (Specht et al., 2016). Given the fiscal realities of Haiti, we anticipate that inclusive education there is more likely to be implemented in regular classes rather than specialized, segregated classes. This makes the research in Haiti - and resulting mobilization of knowledge - a critical and distinctive comparative and international feature that impacts other parts of the world. For Canadian scholars, comparative research on inclusive education is critical in advancing knowledge on how effective inclusive education can be implemented in Canadian schools particularly with increasingly diverse student populations (Porter \& Towell, 2017). As educators globally continue to struggle with the practice of inclusive education, particularly with those with complex needs, the experiences of teachers in low-resource contexts such as Haiti can provide examples of what can be done elsewhere.

Finally, our research has demonstrated that no matter the context, school leaders play a significant role in shaping the beliefs and practices of educators, students, and parents with regard to inclusive education (Sider et al., 2021b). Let me share some quotes from interviews which illustrate the importance of school leaders in fostering inclusive school contexts. A principal in Ghana, when reflecting on his focus on providing professional development sessions to teachers, stated that, "Teachers need to know about disabilities and limitations but also what children can do." A principal in Canada commented in an interview that, "I say to staff right at the beginning, if you feel like running away, that's when you need to run into my office. When you find that you are withdrawing and you're feeling overwhelmed, that's when you need to run in, not out." Another Canadian principal shared an illustration of how a parent gave him a hug at the end of the meeting because, in the parent's words, "I have never had someone want to include my kid in the school before." Another school administrator, in discussing the importance of care, stated that, "Relationships are the foundation of everything I do as a school administrator." These illustrative quotes demonstrate how a leader's strengths-based perspective and advocacy can influence teachers in the school. They also serve as another illustration of how comparative research can shed light on common challenges, and responses, to educational issues globally. 
I have used the research I am involved with to illustrate the importance of care, particularly regarding inclusive education, as we consider the future of comparative education research. Inclusive education certainly provides a logical example of the ethic of care since it is foundational to the very concept of inclusive education. However, it is also important to consider care in the ways in which we do comparative and international research. This is certainly not a new idea but I believe it is one that needs to be even further heightened as we look to the future. Let me illustrate the way in which the very methodological approaches of comparative and international education needs to centre care via the research we engage with in Haiti. Haitian culture values oral traditions, collective-based knowledge, and a strong sense of community (Sider et al., 2019). As a result, community-based participatory research methodologies that prioritize local knowledge in identifying inclusive education practices that are contextually and culturally relevant are critical (Schuelka \& Johnstone, 2012). These approaches take into consideration the diverse lived experiences of the participants in every aspect of this research (Tikly \& Bond, 2013). This approach is particularly important in contexts such as Haiti which have experienced historical oppression (Neufeldt \& Janzen, 2021). Communitybased participatory approaches prioritize research of importance to the community so that knowledge and action for social change are congruent in addressing community needs (Tikly \& Bond, 2013). Through the engagement of key stakeholders at multiple levels (i.e., from the formation of the research partnership to participants including students, principals, teachers, and those who work in disability rights organizations), a community-based, participatory approach ensures that the voices and needs of diverse community members are honoured throughout the research process (Neufeldt \& Janzen, 2021). Care for the topics of our research and the methods we use is critical for our work in complex times.

Comparative and international education is critical in this process of understanding inclusive education:

"...comparative education offers a starting point for improving our education systems and our classroom practices. It also challenges us to think broadly about the link between local practices and global issues, and to explore the overlapping values and social systems that underpin the educational enterprise itself. For teachers, an understanding of the comparative education literature helps for reflection on issues of concern in their own classrooms such as diversity, conflict/peace, teaching approaches, curriculum, and classroom organization in a wider global context, and for learning from the innovations, experiences, and practices of other teachers, schools, countries, and regions". (Bickmore et al., 2017, p. 2)

My research on inclusive education for students with disabilities is not just research. It is an opportunity, a starting point as Bickmore et al. (2017) state, to engage in my own commitment to reflect and actively participate in the world, particularly with those with complex needs. It is part of the ethic of care and relationality that I believed we are called to engage with in complex times and spaces. In many ways, it reflects Fazal Rizvi's (2008) epistemic virtues: Thinking interculturally, relationally, historically, critically, and reflexively. It is also an honouring of Kwame Appiah's call that, "At the heart of modern cosmopolitanism is respect for diversity of culture, not because cultures matter in themselves, but because people matter, and culture matters to people" (Appiah, 2008, 
p. 88). This ethic of care is not just about the focus of our research or the way in which we engage in our research. It is an ethic which should permeate our very being as we engage in conversations, in listening to, and in walking with those who share this human existence.

Let me finish this section with a challenge for the future and how we as comparative and international education scholars demonstrate care. This reflects the question that I posit at the beginning of this article: What can inclusive comparative and international education research look like? I am not referring to inclusive education but how we can be inclusive of a wide range of scholars who may not see themselves as involved with comparative and international education. In a complex time, we need to demonstrate care for all research because all educational research is now comparative and international. We need to provide opportunities to encourage comparative and international research and learning that go beyond the "traditional" aspects of comparative and international education research. This raises two further questions that I believe we need to address: How might comparative and international education societies serve as an inclusive umbrella under which many different individuals and organizations can participate? How can we be deliberately inclusive? Be inviting others to share in this space we can extend our work in critiquing systems where we see privilege and injustice, shining a light and working to dismantle systems and structures, and we need to be beacons of care where scholars and people generally - can see that we care for them and we care deeply for the human condition.

\subsection{Caution}

Finally, I turn to some areas of caution, the final "C", that I would raise as we consider complexity and care as key aspects for comparative and inclusive education going forward. Understanding the complexity of the work we do from an ethos of care is critical from my perspective. I offer these cautions not to serve as roadblocks or barriers but so we can be aware of potential challenges and pitfalls. Moving forward we need to seriously consider how we can ensure that our work is relevant and has integrity.

First, we need to be honest and transparent about our failures in comparative and international education research. Comparative and international education has been guilty at times of following a westernized, neo-colonial model. In this research, we have observed and documented education in other jurisdictions, particularly in the global South, applying judgement and criticism of educational experiences and systems that may differ from what is normative or traditional. We have presented our findings at comparative and international education conferences to audiences that are primarily from the global North. Thankfully, we have come some distance from this more traditional, anthropological approach. We need to recognize that these approaches, even when community-based, participatory research was the goal, often included control of the research processes - and funding - from the global North.

I situate this caution within a recognition of my own failures in this regard. I fully believe that all comparative research should engage local partners and be completed in collaboration with colleagues from the contexts within which I work, whether that is Canada, Haiti, or Ghana. I have made significant efforts, often at what I perceived to be the "efficiency" of a research study, in this regard. For example, I wrote a manuscript on mental health of Haitian high school students following the 2010 earthquake with a Haitian medical student. We worked collaboratively in collecting data, analyzing it, and 
writing a case study based on it. It was truly collaborative. Around the same time, I was asked to explore a form of teacher professional development in Egypt. I rushed into the assignment, traveled to Egypt multiple times, met with teachers and other educational stakeholders, collected data, analyzed the data, and reported on the findings. I did all this without significantly engaging local colleagues in the process. Later, when I reflected on the process, I realized that I had not been participatory; in fact, I had transposed a western tradition of research into a complex context of which I had very little knowledge. I had failed.

My experience in the research project in Egypt mirrors what Asare et al., (2020) have identified in research partnership experiences in sub-Saharan Africa in which partnerships can reproduce inequities. However, Asare et al. (2020) also identify practices that enhance more equitable partnerships, for example, joint-initiated projects which are long-term in nature. Asare et al. conclude that "the locus of control in initiating a project had a key bearing on the equity of relations" (p. 16). In the project I had engaged with in Egypt, the locus of control had moved from the school which initiated the project to me. The result was that the relationship became inequitable. I share this example of failure, not to shine light on my research mistakes (there are plenty more I could share) but to provide an illustration that these failures in research processes and partnerships do not need to be the end of the story. We need to be transparent in our research aims, practices, and even our failures. We can learn from the mistakes if we acknowledge them.

Although I have failed by not always fully and authentically engaging others in the research process, failure can serve as a way forward, a signpost that points us in a new and better direction. This also points us to the key question I have raised in this article, "How can comparative and international education research be inclusive?" A key aspect of inclusion and care is reciprocity. In complex times, it is particularly important that we see research as reciprocal and keep questions such as "How does everyone benefit from this research?" and "Who is driving and controlling the research?" at the front of our research.

Second, as part of the research process in complex times and with care as a foundational ethical value, we need to ensure that we continue to interrogate our privileges and subjectivities. Sometimes, as I did with the research project in Egypt, we rush into a research study without fully understanding our positionality in and with the research. Sustainable change is often best pursued through locally and regionally driven efforts that identify relevant issues and leveraging the assets on the ground to make that innovative change happen (Brissett, 2018). Thus, a caution for those of who live in the global North, is to be particularly and fully aware of engaging in research in the global South or with Indigenous communities in our contexts. When we are invited to engage in research in these contexts, we need to be mindful of ensuring the locus of control remains deeply held by local colleagues and participants.

In the Canadian context, there is an increasing recognition of the generational trauma and harm that have been experienced by Indigenous peoples. The Truth and Reconciliation Commission investigated the harms done through such tools of colonialism as residential schools. In 2015, it released Calls to Action to frame a new way forward for Indigenous and non-Indigenous people in Canada (TRC, 2015). However, as some Indigenous leaders have said, "We rush to reconciliation while truth still needs to be found out" (Donald, 2021) and "We need to think more about righting our relationships instead of reconciliation" (Ottman, 2021). These cautions to consider who we are in relationship to others, those who came before, those who are here now, and those who 
will come after, will help ensure that our research is not just a "snapshot" of a current situation but a recognition of historical factors - and future possibilities - as aspects to consider in our research. Being fully aware of our research biases and blind-spots can help us in ensuring that we are not just doing research "on" participants but "with" them.

Finally, let us put relationships at the heart of our research. This may seem a bit too naïve and simplistic, even "non-scientific." However, over my research career, I have come to increasingly recognize that research is a relational act. Whenever we are asked to work as part of a research team, there is a relational invitation. When we interview participants, even if we have scripted questions, there is an element of trust, a core aspect of relationships. In this aspect of relational space, I turn again to what I can learn from Indigenous scholars, one of whom has described ethical relationality as

"an ecological understanding of human relationality that does not deny difference, but rather seeks to more deeply understand how our different histories and experiences position us in relation to each other. This form of relationality is ethical because it does not overlook or invisibilise the particular historical, cultural, and social contexts from which a standpoint arises. It puts these considerations at the forefront of engagements across frontiers of difference." (Donald, 2013, p. 19).

Patton (2016) explains this as "understanding interrelationships, engaging with multiple perspectives, and reflecting deeply on the practical and ethical consequences of boundary choices" (p. 8).

These are powerful reminders that it is through relationships that we seek to truly understand the human experience which is at the heart of why we engage in comparative and international education research. You can engage in difficult conversations when you have a relationship with another. You can learn, unlearn, and relearn across differences. Of course, relationships and trust take time and effort to foster. We need to recognize that we need to build "relationships over a longer period of time to create trust ... [which] requires patience and careful interactions, and specific capabilities on the part of the organizations and individuals involved' (Kolk \& Lenfant, 2015, p. 21). Fransman and Newman (2019) articulate that in research "trust is key as well as creating spaces for listening, reflecting and imagining' (p. 535). It seems to me that ethical relationality, that is, relationships that are not transactional but which authentically seek to know the other, are particularly important in the complex, divisive times in which we live and in what is sure to be more challenging times in the future.

\subsection{Complexities and Continuances}

I am left in this tension of living between and within complexity and care. I live in a world that has ugliness and beauty, I am filled with despair and yet I have hope, I see systemic injustices and I see acts of kindness, of compassion, and of love, I see structural barriers and I am daily invited to decide what I'm going to do about those. As I consider the future of comparative and international education research, it seems that these personal tensions are also collective tensions. We experience the world individually but also in community; it is a shared experience. Many years ago, a wise Haitian colleague taught me a Haitian Creole proverb, "Piti piti ti pay pay zwazo fe niche" which translates into "Little by little, straw by straw, a bird builds its nest." This has served as a powerful analogy for me about the comparative and international education research work that I have been involved with: 
Small acts of unpacking the human condition and of collectively addressing challenges, can lead to solidarity in fostering a more inclusive and equitable world.

So, what can inclusive comparative and international education research look like going forward? As we live in the complexities, may we live and work with care, to ensure we leave the world a better place than what we inherited. The goal of inclusive education is to welcome every child into their local school where they - and their peers - can experience learning in community. It is not always easy and there are lots of challenges that may arise. Conflict and differences of opinions can emerge. Restoration and relationship-building are often outcomes of the formal learning. In a similar way, comparative education research has the opportunity to be inclusive. Complexities exist in our world which should not dissuade us from engaging in research but should entice us to further explore ways in which we can address these complexities. Framing our research with a deep desire to care for each other and our world, through an ethic of relationality, provides an inclusive and compelling way forward for the work of comparative and international education.

\section{References}

Absolon, K. E. (2016). Wholistic and ethical: Social inclusion with Indigenous peoples. Social Inclusion, 4(1), 44-56.

Ainscow, M., \& Sandill, A. (2010). Developing inclusive education systems: The role of organisational cultures and leadership. International journal of inclusive education, 14(4), 401-416.

Appiah, K. A. (2008). Education for global citizenship. Yearbook of the National Society for the Study of Education, 107(1), 83-99.

Asare, S., Mitchell, R., \& Rose, P. (2020). How equitable are South-North partnerships in education research? Evidence from sub-Saharan Africa. Compare: A Journal of Comparative andInternationalEducation.DOI:10.1080/03057925.2020.1811638

Bickmore, K., Hayhoe, R., Manion, C., Mundy, K., \& Read, R. (Eds.). (2017). Comparative and international education: Issues for teachers. Canadian Scholars' Press.

Brissett, N. O. M. (2018). Sustainable Development Goals (SDGs) and the Caribbean: Unrealizable promises? Progress in Development Studies, 18(1), 18-35.

Cardinal, T., Murphy, M. S., \& Huber, J. (2019). Movements toward living relationally ethical assessment making: Bringing Indigenous ways of being, knowing, and doing alongside narrative inquiry as pedagogy. Revista Interuniversitaria de Formación del Profesorado, 33(3), 121-140.

Clandinin, D. J. (2013). Engaging in narrative inquiry. Routledge.

Clandinin, D. J., \& Connelly, F. M. (2004). Narrative inquiry: Experience and story in qualitative research. John Wiley \& Sons.

Clandinin, D. J \& Connelly, F. M. (1998). Personal experience methods. Collecting and interpreting qualitative materials. In N. D. Denzin \& Y. S. Lincoln (Eds.) Collecting and interpreting qualitative materials (pp. 150-178). Sage Publications. 
Donald, D. (2013). On making love to death: Plains Cree and Blackfoot wisdom. In Smith, M. (Ed.)) Transforming the Academy: Essays on Indigenous Education, Knowledges and Relations (pp. 14-19).

Donald, D. (June 1, 2021). Presentation at Canadian Society for the Study of Education Annual Conference.

Fransman, J., \& Newman, K. (2019). Rethinking research partnerships: Evidence and the politics of participation in research partnerships for international development. Journal of International Development, 31, 523-544.

Frayer, L. (2021). Indian is the world's biggest vaccine maker. Yet only $4 \%$ of Indians are vaccinated. NPR. https://www.npr.org/sections/ goatsandsoda/2021/06/29/1011022472/india-is-the-worlds-biggest-vaccinemaker-yet-only-4-of-indians-are-vaccinated

Fullan, M., Quinn, J., \& McEachen, J. (2017). Deep learning: Engage the world change the world. Corwin Press.

Larsen, M. (2013). Pensamiento innovador en Educación Comparada. Madrid: UNED.

Kolk, A., \& Lenfant, F. (2015). Partnerships for peace and development in fragile states:

Identifying missing links. The Academy of Management Perspectives, 29(4), 422-437.

Merryfield, M. M. (2000). Why aren't teachers being prepared to teach for diversity, equity, and global interconnectedness? A study of lived experiences in the making of multicultural and global educators. Teaching and Teacher Education, 16(4), 429-443.

Neufeldt, R. C., \& Janzen, R. (2021). Learning from and with community-based and participatory action research: Constraints and adaptations in a youth-peacebuilding initiative in Haiti. Action Research, 19(1), 91-109.

NPR (2021). More graves found at new site, Canadian Indigenous group says. https:// www.npr.org/2021/07/01/1012100926/graves-found-at-new-site-canadianindigenous-group-says

OECD (2018). Preparing our youth for an inclusive and sustainable world: The OECD PISA global competence framework. https://www.oecd.org/education/Globalcompetency-for-an-inclusive-world.pdf

Ottman, J. (June 1, 2021). Presentation at the Canadian Society for the Study of Education Annual Conference.

Patton, M. Q. (2016). State of the art and practice of developmental evaluation. In Patton, M. Q., McKegg, K., \& Wehipeihana, N. Developmental evaluation exemplars (124). The Guilford Press.

Porter, G., \& Towell, D. (2017). Advancing inclusive education: Keys to transformational change in public education systems. Inclusive Education Canada. https:// inclusiveeducation.ca/wp-content/uploads/sites/3/2013/o7/Porter-and-TowellAdvancing-IE-2017-Online-FINAL.pdf 
Rizvi, F. (2008). Epistemic virtues and cosmopolitan learning. The Australian Educational Researcher, 35(1), 17-35.

Schuelka, M. J., \& Lapham, K. (2019). Comparative and international inclusive education: Trends, dilemmas, and future directions. In A. W. Wiseman (Ed.) Annual Review of Comparative and International Education 2018 (pp. 35-42). Emerald Publishing.

Sider, S. (2014). School leadership across borders: Examining a Canadian-Haitian partnership to support educational capacity-building in Haiti. International Studies in Educational Administration, 42(1), 75-87.

Sider, S. (2019). Peer coaching in a school in Cairo, Egypt: Implementation, barriers, and pathways to effective adoption. International Journal of Mentoring and Coaching in Education, 8(1), 37-51. https://doi.org/10.1108/IJMCE-04-2018-0016

Sider, S. (2020). School principals and students with special education needs in a pandemic: Emerging insights from Ontario, Canada. International Studies in Educational Administration, 48(2), 78-84. http://cceam.net/wp-content/ uploads/2020/o8/ISEA-2020-48-2.pdf $\#$ page $=84$

Sider, S., Desir, C., Jean-Marie, G., \& Watson, A. (2019). Exploring educational opportunities toward gender equity for girls in Haiti. In C. Sunal \& K. Mutua (Eds.). Transforming public education in Africa, Caribbean, and Middle East (pp. 199217). Information Age Publishing.

Sider, S., Morvan, J., \& Borner, M. (2021a). Inclusive and equitable education in Haiti: A case study of civil society organizations and international partnerships to reach the Sustainable Development Goals in a fragile state. Compare: A Journal of Comparative and International Education. https://www.tandfonline.com/doi/fu ll/10.1080/03057925.2021.1941771

Sider, S., Maich, K., Morvan, J., Villella, M., Ling, P., \& Repp, C. (2021b). Inclusive school leadership: Examining the experiences of school principals in supporting students with special education needs. Journal of Research in Special Educational Needs, 21(2). https://doi.org/10.1111/1471-3802.12515

Specht, J., McGhie-Richmond, D., Loreman, T., Mirenda, P., Bennett, S., Gallagher, T., Young, G., Metsala, J., Aylword, L., Katz, J., Lyons, W., Thompson, S., \& Cloutier, S. (2016). Teaching in inclusive classrooms: Efficacy and beliefs of Canadian preservice teachers. International Journal of Inclusive Education, 20 (1), 1-15.

Tarc, P. (2013). International education in global times: Engaging the pedagogic. Peter Lang.

Tikly, L., \& Bond, T. (2013). Towards a postcolonial research ethics in comparative and international education. Compare: A Journal of Comparative and International Education, 43(4), 422-442.

TRC (2015). Truth and reconciliation commission of Canada: Calls to action. http://trc. ca/assets/pdf/Calls_to_Action_English2.pdf

Vertovec, S. (2009). Transnationalism. Routledge.

Zemach-Bersin, T. (2008). American students abroad can't be global citizens. Chronicle of Higher Education, 54(26), A34. 